\title{
Assessment of Climatic Water Balance and Quality of Shallow Aquifer Groundwater Around Al-Garraf River (Southern Iraq)
}

\author{
Received : 7/12/2017
}

Accepted : 18/1/2018

\author{
Moutaz A. Al-Dabbas, Ayser Al-Shamma, Kareem Ghful Al-Mitawki* \\ Department of Geology, College of Science, University of Baghdad, Baghdad, Iraq \\ kareem.ghafel@qu.edu.iq
}

\begin{abstract}
Al- Gharraf River is one of the most important and longest-running rivers in southern Iraq, where water is moving from Kut towards Dhi Qar governorate. In this study, the climatic water balance of the studied area was determined by using the climatic parameters of the Al-Hay meteorological station.

The geology and the formal shallow unconfined aquifer of the area is quaternary sediments which are overlain lower Miocene carbonates. The recharge of groundwater depends mainly on rainfall and the irrigation water. The analysis of climatic parameters, gave the idea that the average monthly temperature is ranging from 17.1- $45.4 \mathrm{C}^{\circ}$, rainfall $(0-31.7 \mathrm{~mm})$, evaporation $(526.4 \mathrm{~mm}$ in July) and $(49.1 \mathrm{~mm}$ in January). The water surplus is about 55.327 while the water deficit is $1678.83 \mathrm{~mm}$. The analysis of major ions, gave the idea that the studied wells recorded high TDS, which ranges between $1116 \mathrm{mg} / \mathrm{l}$ to2300 $\mathrm{mg} / \mathrm{l}$. Durov and Piper diagrams were used to present the data. Most of the groundwater samples are plotted in fields 5 which indicates no domination of cation or anion, this mean that process was mixed the recharge groundwater with surface water (rain and irrigation). All groundwater samples are brackish water.
\end{abstract}

\section{Keywords}

Water balance, Shallow Aquifer, Groundwater, Water quality, Facies

\section{Introduction:}

Shallow groundwater in the saturation area affects soil content from moisture and has an effect on vegetation and is affected by climate through the movement of water through the capillary property and its up movement through the plant roots from underground reservoirs that affect the surface processes of the earth. In contrast to deep-water conditions, shallow groundwater maintains the high soil moisture in the root region by the capillary process [1], which depends on the properties of the soil hydraulic and the aquifer. Ferguson and Maxwell (2010) [2] showed that the sensitivity of the hydrological response to climate change is closely related to the interactions between groundwater and surface processes.

Increased salinity from irrigated agriculture is one of the first forms of groundwater pollution. Much of saturation salinity groundwater are related to the low efficiency of irrigation projects and the absence of modern infrastructure to treatment the waste water which leads to groundwater level rise and degrading of groundwater. Also, another leading to increased salinity of soil and groundwater due to direct evaporation from the saturated zone. The use of more irrigation water to reduce salinity concentration by washing has an effect on 
groundwater quality. Other contributions can contribute to increased salinity through the movement of brackish water from the soil downwards towards the groundwater, or sometimes the level of groundwater increases, causing soil salts to melt leading to higher salinity in groundwater.

The study aimed to calculate the climate water balance by analyzing the climatic parameters of its contribution to groundwater recharge and its relation to improving the quality of shallow water around the river and at a distance from the river in the area between Qal'at Salih and Al Gharaf District in southern Iraq.

\section{Study Area:}

Al-Gharraf River basin is located in the southeastern sector of Iraq and surrounded by vast and agricultural lands. The study area extends from Al-Kut dam till near Dhi Gar (south-Iraq), along the transverse profile which extends (nearly $170 \mathrm{Km}$ ) E-W between the Tigris and Euphrates Rivers on the Mesopotamia plain. It locates between the coordination's $\left(32^{\circ} 31^{\prime} 21.40^{\prime \prime} \quad \mathrm{N}\right), \quad\left(45^{\circ} 49^{\prime} 17.38 " \mathrm{E}\right) \quad$ and $\left(31^{\circ} 05^{\prime} 41.60^{\prime \prime} \mathrm{N}\right),\left(46^{\circ} 29^{\prime} 22.05^{\prime \prime E}\right)$. The highest ground level at Al-Kut dam and Al-Garaaf city (nearly location at the end of Al-Graaf River) is about $(17 \mathrm{~m}),(5 \mathrm{~m})$ above sea level respectively (Fig 1). 


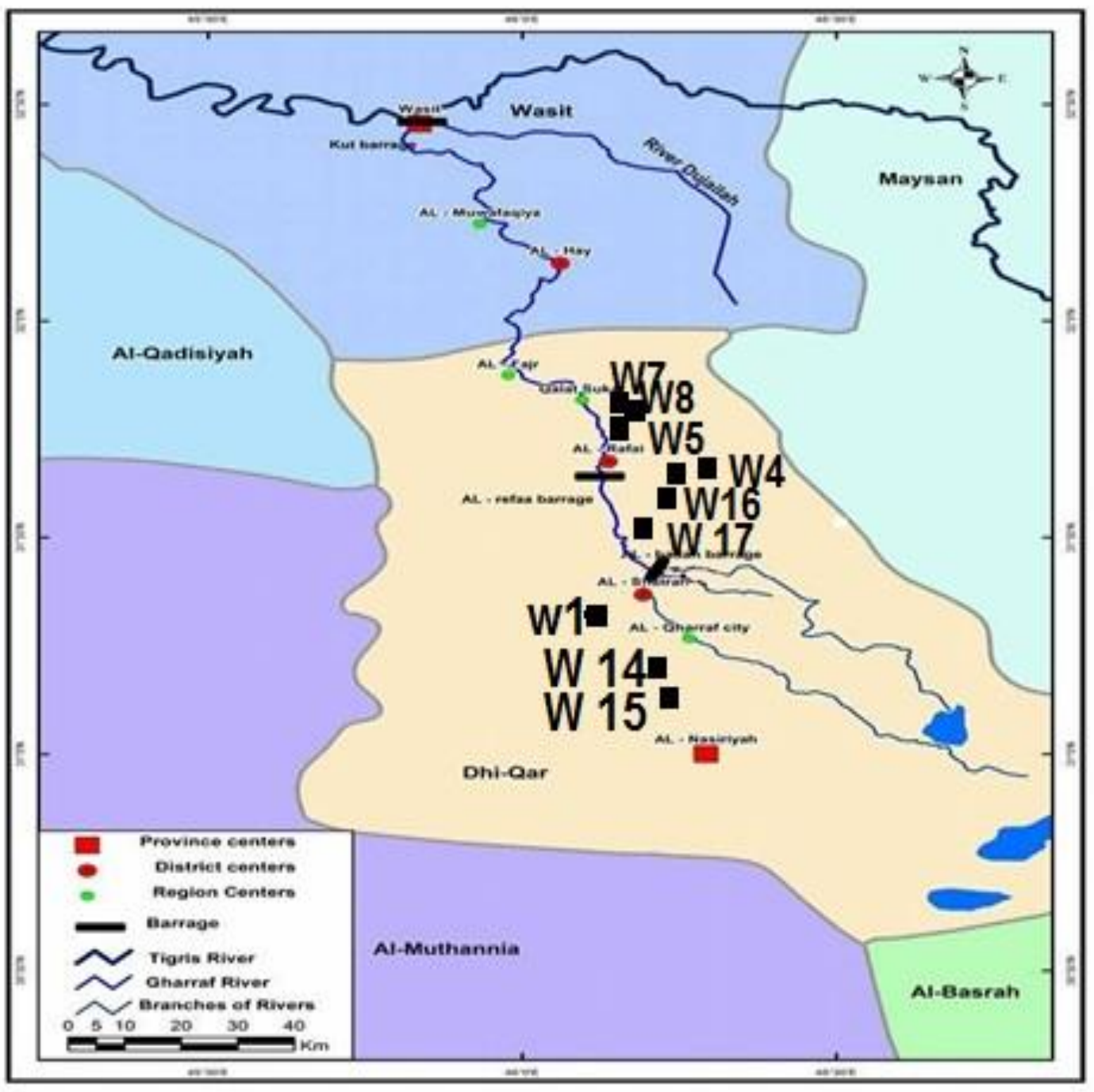

Figure(1): The studied area

\section{Geological Setting:}

The study area extends along a part of Mesopotamia flood plain. The Mezopotamia plane comprises a lake, marsh complex. The thickness of the Quaternary deposit exceeds $250 \mathrm{~m}$. The upper part of the sequence (mostly of Holocene age) comprises fluviatile flood silts and Aeolian silts (Philip, 1969;Kuked and
Saadalla, 1975). The Quaternary sediments are unconsolidated and usually finer grained than the underlying formations [6].

\section{Climate Parameters:}

The climatic data for the study area was taken for the period, (1992-2016) from Al-Hay meteorological station,. The monthly values of climatic elements are shown in table (1).

Table(1): Monthly values of climatic elements

\begin{tabular}{|c|c|c|c|c|c|c|}
\hline $\mathrm{M}$ & $\left(\mathrm{C}^{\mathrm{O}}\right)$ & $\begin{array}{c}\mathrm{P} \\
(\mathrm{mm})\end{array}$ & $\begin{array}{c}\mathrm{E} \\
(\mathrm{mm})\end{array}$ & $\mathrm{RH}(\%)$ & $\begin{array}{c}\mathrm{S} \mathrm{S} \\
(\text { hours })\end{array}$ & $\begin{array}{c}\mathrm{W} \\
(\mathrm{m} / \mathrm{sec})\end{array}$ \\
\hline
\end{tabular}




\begin{tabular}{|c|c|c|c|c|c|c|}
\hline Oct. & 35.7 & 4.3 & 203.8 & 35.7 & 8.6 & 3.3 \\
\hline Nov . & 25.8 & 20.5 & 119.6 & 25.8 & 7.4 & 3.1 \\
\hline Dec . & 19.6 & 18.5 & 87.4 & 19.6 & 7.9 & 2.9 \\
\hline Jan. & 17.1 & 30.9 & 49.1 & 70 & 6.3 & 2.2 \\
\hline Feb. & 20.1 & 31.7 & 93.9 & 61 & 7.4 & 2.9 \\
\hline Mar.. & 25.6 & $\mathbf{1 6 . 0}$ & 156.0 & 52 & 7.9 & 3.7 \\
\hline Apr. & 32 & 13.7 & 243.2 & 45 & 8.3 & 3.8 \\
\hline May. & 38.6 & 4.3 & 367.9 & 38.6 & 9.6 & 3.9 \\
\hline Jun. & 43.6 & $\mathbf{0 . 1}$ & 490.1 & 43.6 & 11.3 & 5 \\
\hline July. & 45.3 & $\mathbf{0 . 0}$ & $\mathbf{5 2 6 . 4}$ & 45.3 & 11.6 & 5.1 \\
\hline Aug. & 45.4 & $\mathbf{0 . 0}$ & 476.7 & 45.4 & 11.4 & 4.5 \\
\hline Sep. & 41.9 & $\mathbf{0 . 8}$ & 396.6 & 41.9 & 10.2 & 4 \\
\hline Mean & 32.5 & $\Sigma 140$. & 267.55 & 43.658 & 8.991 & 3.7 \\
\hline
\end{tabular}

$\mathrm{M}=$ month, $\mathrm{C}^{\mathrm{O}}=$ Temperature, $\mathrm{P}=$ Precipitation, $\mathrm{E}=$ Evaporation,

RH= Relative Humidity, SS $=$ Sunshine,$W=$ Wind,$\Sigma=$ Sum

Evapotranspiration was corrected according to latitude for each month[7]. The climatic water balance of the study area calculated by using a Thornthwaite method[8].

\section{Sampling and Analytical Procedure:}

A seventeen Groundwater samples were collected through March /2017 and July/2017 for wet and dry seasons respectively in ployethylene bottle. To avoid cross contamination, bottles are rinsed with the same water. Electrical conductivity (EC) and total dissolved solids and $(\mathrm{pH})$ were measured using digital meters after sampling. Water samples were analyzed for

The mean monthly relative humidity (RH\%) is ranging from $19.6 \%$ in December to $70 \%$ in January. Maximum temperature is the most important climatic element. The mean monthly temperature $\left(\mathrm{C}^{\circ}\right)$ ranging from $\left(8.9-38.6 \mathrm{C}^{\circ}\right)$. The maximum mean monthly wind speeds (W) recorded in July $(5.1 \mathrm{~m} / \mathrm{sec})$ and the minimum in January $(2.2 \mathrm{~m} / \mathrm{sec})$. Sunshine duration(SS) is one of the most important climatic factors that have a significant impact on the amount of evaporated water. Increases in sunshine mean increased temperature and increased evaporation (E). The highest mean was recorded in June chemical constituents such as $\mathrm{Ca}^{+2}, \mathrm{Mg}^{+2}, \mathrm{Na}^{+1}$, $\mathrm{K}^{+1}, \mathrm{HCO}_{3}^{-1}, \mathrm{Cl}^{-1}, \mathrm{SO}_{4}^{-2}$.

\section{Data Management:}

Climatic elements:

The high amount of rainfall $(\mathrm{R})$ and relative humidity in $(\mathrm{mm})$ through the month (November, December, January, February, March and April) this month represented the wet period and the other months represented the dry period. The maximum and minimum mean monthly rainfall were $(31.7 \mathrm{~mm})$ in February and in July and August.

The annual monthly mean rainfall was (140.8mm).

(11.6 hours / day) while the lowest was in January (6.23 hours / day).

Thornthoite said that the evapotranspiration is the amount of water vapor produced from soil covered with plants. The Thornthwaite method was chosen from among different methods, because there is no daily monitoring of climate factors at hand, as well as easy to apply [8]. Thornthwaite's equations were based on the relationship between the evaporation capacity of an area, 
the air temperature and the number of sunrise hours from morning to sunset. PE was Calculated in $(\mathrm{mm})$ and corrected by multiplying its value with the index $(\mathrm{K})$ (Table 3). The value of the $\mathrm{K}$ index was calculated depending on the months and location of the climatic station from the latitudes [20].

Table (2): Monthly averages for PE (potentional evapotranspiration in $\mathrm{mm}$ ) before and after correction for the period (1992-2016), Al-Hay Meteoric Station

\begin{tabular}{|c|c|c|c|c|c|}
\hline M & $\mathrm{C}^{\circ}$ & $\mathrm{j}=(\mathrm{t} / 5)^{1.514}$ & PE(mm) & $(\mathbf{K})$ & PEc \\
\hline Jan & 17.1 & 6.434511 & 6.896 & 0.89 & 5.516 \\
\hline Feb & 20.1 & 8.218608 & 12.944 & 0.86 & 11.1318 \\
\hline Mar & 25.1 & 11.50444 & 30.750 & 1.03 & 31.672 \\
\hline Apr & 32 & 16.61715 & 79.193 & 1.08 & 85.528 \\
\hline May & 38.6 & 22.07255 & 164.393 & 1.19 & 195.627 \\
\hline Jun & 43.6 & 26.54251 & 264.196 & 1.19 & 314.393 \\
\hline July & 45.3 & 28.12497 & 309 & 1.21 & 373.89 \\
\hline Aug & 45.4 & 28.21902 & 309.286 & 1.15 & 355.678 \\
\hline Sep & 41.9 & 24.99145 & 226.282 & 1.03 & 233.070 \\
\hline Oct & 35.7 & 19.61097 & 121.274 & 0.98 & 118.848 \\
\hline Nov & 25.8 & 11.99366 & 34.228 & 0.88 & 30.120 \\
\hline Dec & 19.6 & 7.911068 & 11.734 & 0.87 & 9.152 \\
\hline
\end{tabular}

(M.month, $\mathbf{C}^{\circ}$.Temperature, PE. Potentional evapotranspiration,K.correction factor,PEc.Correction evapotranspiration)

\section{Results and Discussion:}

Based on the results of this study, the temperature is ranging between $17.1-45.4 \mathrm{C}^{\circ}$, rainfall $(0-31.7 \mathrm{~mm})$ and evaporation $(526.4 \mathrm{~mm}$ in July) and (49.1 mm in January) (table.1). Strong relationship between climatic elements and the natural water cycle [5]. Intensity and longtime of rainfall influence the water quality via water infiltration downward a groundwater.

The surface water level in Al-Garaaf River ranges between $10.25 \mathrm{~m}$ to $10.65 \mathrm{~m}$ above sea level (asl), while the groundwater level ranges between $6 \mathrm{~m}-8 \mathrm{~m}$ (a.s.1.).

Water Surplus and Water Deficit Calculation:
Water Surplus can be determined from correceted potencial evapotranspiration which was calculated using Thorntwiate equations,

$P E=$ PEc when $P \geq P E c \quad P E=P$ when $P<$ PEc

PE: Potential evapotranspiration

PEc: Corrected evapotranspiration

$\mathrm{P}$ : Rainfal WS=P-PEc ; P>PEC or PEc $=\mathrm{PE}$ WD=PEc-P ; P $<$ PEc $\quad P=P E$

The monthly corrected potential evapotranspiration (PEc) were calculated in (Table. 2 and 3), as it shows that there is a water deficit from the beginning of March to the end of November, while the water surplus from December $(9.375 \mathrm{~mm})$ to the end of February with an annual value of $(24.77 \mathrm{~mm})$. 
The maximum value of water deficit was in June $(355.5 \mathrm{~mm})$, while the minimum water deficit was during December, January and February (Table.3).

\section{Water Quality Assessment}

The concentration of cations and anions for each study area is shown in Table 4. The analyzes indicate that all water samples have a weak base with a $\mathrm{pH}$ value ranging from 7.1 to 7.5. The distribution of the ions gives an impression of increasing as we move away from the river. Where well 1 ( fig.1) is relatively the most concentrated of dissolved ions. This situation may be attributed to the weakness of the interaction between the river and the groundwater. Secondly, as indicated by the results of the calculation of the climate water balance, where the large deficit and increased levels of evaporation and therefore the lack of water with light concentrations to dilute the concentration of groundwater $[10,11$,$] .$

The maximum value of water surpuls is 25.384 in January, 20.568 in Feburary while the minimum surpulus in December (9-375mm)

Table (3) Water Surplus and Water Deflect of the study area.

\begin{tabular}{|l|l|l|l|l|l|}
\hline Month & P $(\mathrm{mm})$ & \multicolumn{1}{|c|}{ PE } & PEc $(\mathrm{mm})$ & WS (P-PEc) & WD (PEc-P) \\
\hline Oct & 4.3 & 121.274 & 118.848 & $\mathbf{0 . 0}$ & $\mathbf{1 1 4 . 5 4 8}$ \\
\hline Nov & $\mathbf{2 0 . 5}$ & $\mathbf{3 4 . 2 2 8}$ & $\mathbf{3 0 . 1 2 0}$ & $\mathbf{0 . 0}$ & $\mathbf{9 . 6 2}$ \\
\hline Dec & $\mathbf{1 8 . 5}$ & 11.734 & $\mathbf{9 . 1 5 2}$ & $\mathbf{9 . 3 7 5}$ & $\mathbf{0 . 0}$ \\
\hline Jan & $\mathbf{3 0 . 9}$ & $\mathbf{6 . 8 9 6}$ & $\mathbf{5 . 5 1 6}$ & $\mathbf{2 5 . 3 8 4}$ & $\mathbf{0 . 0}$ \\
\hline Feb & $\mathbf{3 1 . 7}$ & $\mathbf{1 2 . 9 4 4}$ & $\mathbf{1 1 . 1 3 1 8}$ & $\mathbf{2 0 . 5 6 8}$ & $\mathbf{0 . 0}$ \\
\hline Mar & $\mathbf{1 6 . 0}$ & $\mathbf{3 0 . 7 5 0}$ & $\mathbf{3 1 . 6 7 2}$ & $\mathbf{0 . 0}$ & $\mathbf{1 5 . 6 7 2}$ \\
\hline Apr & $\mathbf{1 3 . 7}$ & $\mathbf{7 9 . 1 9 3}$ & $\mathbf{8 5 . 5 2 8}$ & $\mathbf{0 . 0}$ & $\mathbf{7 1 . 5 2 8}$ \\
\hline May & 4.3 & $\mathbf{1 6 4 . 3 9 3}$ & $\mathbf{1 9 5 . 6 2 7}$ & $\mathbf{0 . 0}$ & $\mathbf{1 9 1 . 3 2 7}$ \\
\hline Jun & $\mathbf{0 . 1}$ & $\mathbf{2 6 4 . 1 9 6}$ & $\mathbf{3 1 4 . 3 9 3}$ & $\mathbf{0 . 0}$ & $\mathbf{3 1 4 . 2 9 3}$ \\
\hline Jul & $\mathbf{0 . 0}$ & $\mathbf{3 0 9}$ & $\mathbf{3 7 3 . 8 9}$ & $\mathbf{0 . 0}$ & $\mathbf{3 7 3 . 8 9}$ \\
\hline Aug & $\mathbf{0 . 0}$ & $\mathbf{3 0 9 . 2 8 6}$ & $\mathbf{3 5 5 . 6 7 8}$ & $\mathbf{0 . 0}$ & $\mathbf{3 5 5 . 6 7 8}$ \\
\hline Sep & $\mathbf{0 . 8}$ & $\mathbf{2 2 6 . 2 8 2}$ & $\mathbf{2 3 3 . 0 7 0}$ & $\mathbf{0 . 0}$ & $\mathbf{2 3 2 . 2 7}$ \\
\hline$\sum$ & 140.8 & & $\mathbf{1 7 6 4 . 3 2 2}$ & $\mathbf{5 5 . 3 2 7}$ & $\mathbf{1 6 7 8 . 8 3}$ \\
\hline
\end{tabular}

Water Surplus as in \% of rainfall is calculated :

WS $\%=\sum$ WS $/ \sum \mathbf{P} \times 100$

WS \% $=40$

Where :

WS= Water Surplus

$\mathbf{P}=$ Precipitation (Rainfall)

Table(4): Concentration of the major components of the groundwater (ppm)

\begin{tabular}{|l|l|l|l|l|l|l|l|l|}
\hline Well. No & $\mathrm{K}^{+}$ & $\mathrm{Na}^{+}$ & $\mathrm{Mg}^{2+}$ & $\mathrm{Ca}^{2+}$ & $\mathrm{Cl}^{-}$ & $\mathbf{S O}_{4}{ }^{2-}$ & $\mathrm{HCO}^{3-}$ & $\mathrm{NO}^{3-}$ \\
\hline W1 & 25 & $\mathbf{2 2 0}$ & $\mathbf{8 3}$ & $\mathbf{1 1 9}$ & $\mathbf{3 4 6}$ & $\mathbf{5 3 3}$ & $\mathbf{1 0 7}$ & $\mathbf{1 . 6}$ \\
\hline W2 & $\mathbf{2 8}$ & $\mathbf{2 4 7}$ & $\mathbf{9 4}$ & $\mathbf{1 3 4}$ & $\mathbf{3 8 9}$ & $\mathbf{5 9 9}$ & $\mathbf{1 2 0}$ & $\mathbf{1 . 8}$ \\
\hline
\end{tabular}




\begin{tabular}{|c|c|c|c|c|c|c|c|c|}
\hline W3 & 23 & 206 & 78 & 112 & 324 & 499 & 100 & 1.5 \\
\hline W4 & 21 & 198 & 68 & 106 & 295 & 396 & 95 & 1.3 \\
\hline W5 & 28 & 246 & 94 & 134 & 388 & 597 & 120 & 1.8 \\
\hline W6 & 25 & 226 & 86 & 123 & 356 & 548 & 110 & 1.7 \\
\hline W7 & 27 & 239. & 91 & 130 & 377 & 579 & 117 & 1.8 \\
\hline W8 & 24 & 219 & 83 & 119 & 345 & 530 & 107 & 1.6 \\
\hline W9 & 20 & 182 & 69 & 99 & 287 & 441 & 89 & 1.38 \\
\hline W10 & 23 & 202 & 77 & 110 & 319 & 490 & 99 & 1.5 \\
\hline W11 & 20 & 185 & 64 & 99 & 277 & 372 & 89 & 1.29 \\
\hline W12 & 22 & 198 & 75 & 108 & 313 & 481 & 97 & 1.1 \\
\hline W13 & 22 & 200 & 76 & 109 & 316 & 486 & 98 & 1.2 \\
\hline W14 & 19 & $\mathbf{1 7 8}$ & 59 & 93 & 259 & 348 & 84 & 1.21 \\
\hline W15 & 20 & 176 & 67 & 96 & 278 & 428 & 86 & 1.34 \\
\hline W16 & 19 & 172 & 59 & 92 & 257 & 345 & 83 & 1.2 \\
\hline W17 & 21 & 184 & 70 & 100 & 290 & 446 & 90 & 1.4 \\
\hline
\end{tabular}

\section{Hydro geochemical facies:}

The geochemical assessment of water can be clarified by using Piper (1944) trilinear diagram [12] and Durov (1948) plot [13].

The concept of hydraulic faces was conceived to understand and determine the composition of water in different categories. Hydrochemical facies are a distinct zones that possesses a chemical effect and types of ion concentrates. By analyzing the location of the samples on the Pipers diagram (Table .3), we find that the water type is a calcium-chloride in field 6 and mixed type (cation-anion exceeds 50\%) in field 9. These field6 and 9 demonstrating the earth alkaline water facies with prevailing $\mathrm{SO}_{4}$ and $\mathrm{Na}$. There is no change in the groundwater hydrochemical facies, although they are relatively high distances. This indicates that the groundwater sources are similar and natural [14].

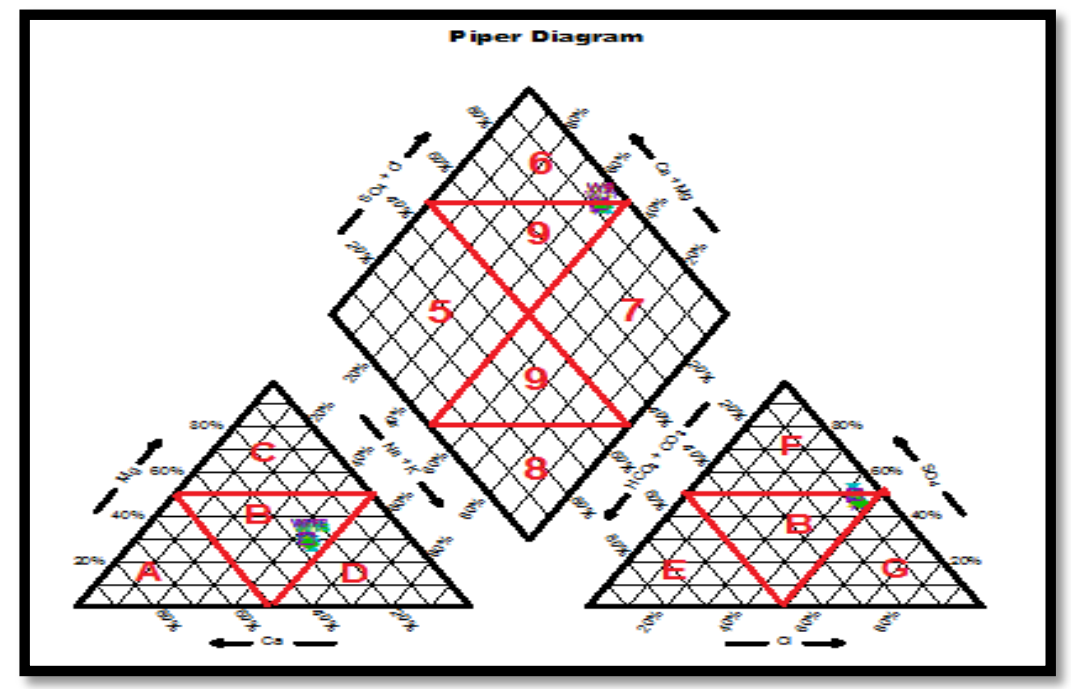

Figure (2): Piper diagram 


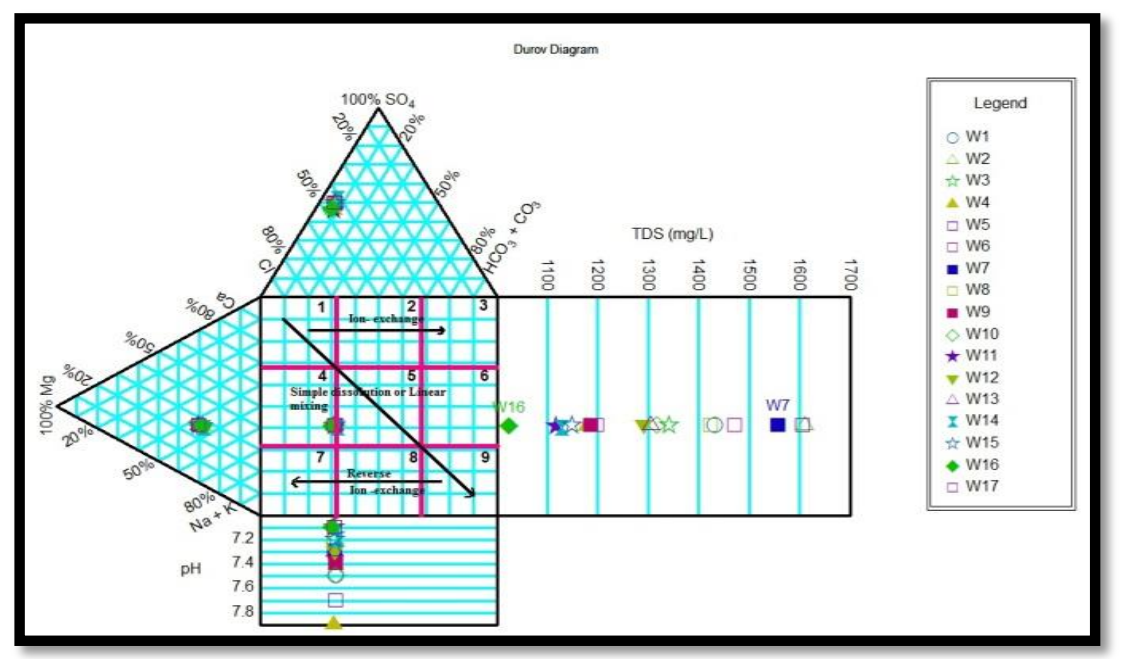

\section{Figure(3): Durov diagram}

Mixed water type prevails in the study area supported by data plotted on Durov diagram (Fig.3 ) that all the sample plot in the field 5 of the Durov plot along the dissolution or mixing line.

\section{Water suitability:}

\section{Water hardness:}

Water hardness is formed in groundwater due to the presence of cations such as calcium and magnesium ions as well as anions such as carbonate ion, chloride, and sulfide in water. It is believed that acidity causes heart disease. The
According to WHO (2006) [18] and IRAQ standard all the water samples are unsuitable for drinking purpose. Total Dissolved Solid ( TDS) is out of the permissible level. According to Altoviski [17] classification all the samples are good for domestic, animals and livestock used.

\section{Table (5): Classification of water based on hardness by Sawyerer and McCarthy}

\begin{tabular}{cc} 
Hardness & Classifica \\
\hline $0-75$ & Soft \\
$75-150$ & Moderate \\
$150-300$ & Hard \\
$>300$ & Very hard
\end{tabular}

Due to relatively high concentrations of bicarbonate ions. There is a prevailing tendency to precipitate calcium and magnesium ions. Therefore, the water becomes highly concentrated in both the reservoir and soil when the groundwater level is high. As a result of these concentrations, the relative concentrations hardness of water in the wells of the study area ranges from (471-721ppm).According to Sawyer and McCatys [15] classification for hardness, water is very hard: of sodium ions in the water will increase as sodium

carbonate The suitability of groundwater for irrigation, depends on its mineral content achieved through: 1. EC, 2. Concentration of sodium ions for cation ratio $3 . \mathrm{HCO}_{3}^{-}$ions. Wilcox [16] cited that Groundwater is classified 
for irrigation purposes based on the concentration of sodium ions and its EC. The ions are expressed in irrigation water by sodium percent and can be found in the following formula\% :

Table (6): Sodium percent water class

Sodium\% Water class

Excellent

20-40 Good

40-60 Permissible ---- All the groundwater samples are in the range (40-60)

60-80 Doubtful

$>80 \quad$ Unsuitable

\section{Recommendation:}

Prevention of the problem of salinity of groundwater requires more efficient irrigation along with the development of drainage projects. This is to reduce the level of groundwater [3]. Assessment of river water quality has often provided the best indication of overall trends in salinity [4].

\section{Conclusion:}

The climate water balance has been calculated to determine the quantity of shallow groundwater aquifer recharge. When analyzing the results, it

\section{References:}

1. Chen, X. and Hu, Q., 2004. Groundwater influences on soil moisture and surface evaporation, J. Hydrol., 297, 285-300, 2004.

2. Ferguson, I. M. and Maxwell, P. J., 2010. Role of groundwater in watershed response and land surface feedbacks under climate change, Water Resoures., 46, WOOF02.

3. Meybeck, M., Chapman, D. and Helmer, R. [Eds]., 1989. Global Freshwater Quality: A First Assessment. Blackwell Reference, Oxford, 306 pp.

4. Williams, W.D.,1987. Salinization of rivers and streams an important environmental hazard. Ambio, 16(4), 180-185 p.

5. Bates, B., Kundzewicz,Z. W., Wu, S., Pulutikof. J.P., 2008. Climate change and
$\left.\mathrm{Na}=\left(\mathrm{Na}^{+}\right) * 100 / \mathrm{Ca}^{2+}+\mathrm{Mg}^{2+}+\mathrm{Na}^{+}+\mathrm{K}^{+}\right)(19)$

The classification of groundwater samples for sodium ratio is expressed in table 6. All water samples are permissible. was found that there was a large water deficit due to high temperature and thus increased evaporation rate. The main source is water from irrigation in addition to infiltrated rain water.

When analyzing the results of groundwater samples, water was found to be mixed and modern. where the concentration of total dissolved ions around $1606 \mathrm{mg} / \mathrm{L}$. The groundwater in the region is unsuitable for human drinking purpose. It can be used for household and animal purposes.

water, intergovernmental panel on climate change secretariat, Geneva, $210 \mathrm{pp}$.

6. Jassim, S. Z and Goff, J.C., 2006. Geology of Iraq, Dolin, Prague and Moravian Museum, Brno, Czech Republic.

7. Al-Dabbas, M and Maiws, S. O., 2016. The water balance of Dujaila area, Wasit Journal for Science and Medicine, 9 (2) 87-96 p.

8. Thornthwait, C. W., 1948. An approach toward a relation classification of climate, Geographical review, Vol.32, 55p.

9. Davis,S. N. and De Wiest, RJM., 1966. Hydrogeology. John Wily, New York, 473p.

10. Ewaid, S. H., \& Abed, S. A. (2017). Water quality index for Al-Gharraf River, southern Iraq. Egypt. J. Aquat. Res. National Institute of Oceanography and Fisheries.,43(2),117- 
122. https://doi.org/10.1016/j.ejar.2017.03 .001

11. Appelo, C. A.J. and Postma,D., 1999. Geochemistry, groundwater and pollution. Rotterdam, A. A. Balkama, 536p.

12. Rafaa, Z, Yehya T. Al-Rawi and Habib., 2014. Hydrochemical situation of Shari Playa lake brines and the contribution of the feeding water to the formation of evaporated minerals, GEOSURV, Vol. 10, No. 2, 2014, Baghdad, Iraq.

13. Piper, A. M., 1944. A graphic procedure in the geochemical interpretation of water analyses. American Geophysical Union Transactions, 25, 914-928.

14. Dueov,S. A., 1948. Classification of natural waters and graphical representation of their composition. Doki. Nauk. USSR. 59(1):8790.

20- Al-Rawai, A.S and Al-Samarai, K. A., 1990. Applied Climatology Book, Ministry of Higher Education and Scientific Research, Baghdad University, 182p.
15. Back, W, Hanshaw,B. B., 1965. Advances in hydroscience. In chemical Geohydrology,49p..

15. Sawer G. N. McCarthy D. L., 1967. Chemistry of sanitary Engineers, P 518.

16. Wicox, L. V., 1995. Classification and use of irrigation waters, US Department of Agriculture, P19.

17. Altoviski,M. E.,1962. Handbook of hydrogeology, Gosgeolitzdat, Mosco, USSR, 614P.

18. WHO. World Health Organization, 2006. Guidelines for drinking water quality, $1^{\text {st }}$ Eddition., V1, Geneva, 515.

19- Todd, D.K., 1980. Groundwater Hydrology, John Willey and Sonn. Inc. Toppan printing company.535p 